\title{
ANÁLISE DOS COMPARTIMENTOS MORFOPEDOLÓGICOS COMO SUBSÍDIO AO PLANEJAMENTO DO USO DO SOLO EM JATAÍ - GO*
}

\author{
Potira Meirelles Hermuche** \\ Gislene Margaret Avelar Guimarães*** \\ Selma Simões de Castro****
}

\section{RESUMO:}

O presente trabalho apresenta uma análise dos condicionantes ambientais do município de Jataí - GO, a partir de seus compartimentos morfopedológicos, como subsídio ao planejamento do uso do solo. A metodologia contou com quatro etapas complementares: definição dos compartimentos morfopedológicos; avaliação da suscetibilidade à erosão Linear; análise da capacidade de uso das terras; e avaliação dos conflitos existentes quanto ao uso atual do solo em relação à referida capacidade de uso. O trabalho mostrou que não existem conflitos no uso atual do solo considerados altos no município.

\section{PALAVRAS-CHAVE:}

Compartimentação Morfopedológica; Suscetibilidade à erosão Linear; Uso do solo; Capacidade de uso; Conflitos.

\section{ABSTRACT:}

The morphopedological compartments analysis for subsidy to the soil planning use of Jataí-GO, Brazil. This paper presents an analysis of the determining environmental factors in Jataí-GO, based on their morphopedological compartments, for subsidy to the planning of the soil use. The methodology consists of four distinct phases: definition of morphopedological compartments; evaluation of susceptibility to Linear erosion; analysis of land use capacity; and the soil use conflicts. The conclusion reached by the analysis was that high conflicts don't exist in the current soil use in Jataí.

\section{KEY WORDS:}

Morphopedological Compartmentation; Susceptibility to Linear erosion; Soil use; Land use capacity; Conflicts.

\section{INTRODUÇÃO}

A expansão da fronteira agrícola no sudoeste goiano, impulsionada pelo Estado, constituiu-se em um processo de mudança da base técnica, que possibilitou o reordenamento do espaço produtivo com mudanças bruscas, numa rápida passagem da modernização à industrialização da agricultura e dessa para a instauração dos complexos agroindustriais. Esse fato possibilitou um alto grau de mercantilização das terras da região favorecendo 0 estabelecimento de grandes propriedades e o fechamento precoce da fronteira agrícola. (KAGEYAMA et al., 1990; CARMO et al. 2002; RESENDE 2002; MIZIARA, 2006).

Nesse processo, a exploração agrícola inicialmente feita nos chapadões, áreas de Latossolos Vermelhos e relevos planos que suportavam o uso intensivo e a mecanização pesada, passou a incorporar as áreas em seu entorno, de maior declividade, com predominância de Neossolos Quartzarênicos, que 
são solos arenosos. Da mesma forma, a atividade pecuária também se expandiu ocupando terras inadequadas para a lavoura e solos inaptos para atividades agropecuárias (ANTUNES, 2006; SILVA, 2006).

Os problemas ambientais decorrentes do uso intensivo, do manejo inadequado e, principalmente, da discrepância entre aptidão e uso do solo têm se agravado na região Sudoeste de Goiás. Além da perda da cobertura de vegetação nativa que leva a processos erosivos devido à associação dos condicionantes naturais do solo e do clima da região e a ação antrópica, Carmo et al.(2002) apontam outras modificações ambientais decorrentes da instalação de complexos agroindustriais, como a introdução monocultural de espécies exóticas de uso comercial, o lançamento de agroquímicos no ambiente, a alta produção de dejetos, a queda da qualidade e quantidade de água, perda de fertilidade dos solos e a perda da biodiversidade.

Outros estudos indentificaram processos de arenização na região após a década de 70 , com forte correlação com a forma de uso e ocupação do espaço (ANTUNES, 2006; SILVA, 2006). De acordo com Antunes (2006), os Neossolos Quartzarênicos degradados ocorrem principalmente nas bacias dos rios Araguaia e nas nascentes dos rios Claro e Caiapó, destacandose como municípios mais afetados Serranópolis e Mineiros, ambos da microrregião Sudoeste de Goiás.

No relatório sobre o estado ambiental de Goiás (GALINKIN, 2003) estima-se que, mantendo-se as mesmas formas de uso e ocupação e os altos índices de desmatamento 'legalizado', os campos e savanas, excetuandose as áreas federais de proteção integral, serão erradicados em 57 anos. Segundo Rodrigues et al. (2003), em quase todo o Estado foram concedidas autorizações para desmatamento, que correspondem a 203.399,02 ha, sendo que a Mesorregião Sul, na qual está incluída a microrregião Sudoeste de Goiás, apresentou uma das maiores taxas entre 2000 e 2002: 47.453,63 ha para a pecuária $(23,33 \%)$ e $9.152,99$ ha para a agricultura $(4,50 \%)$.
Considerando a problemática dessa região no que diz respeito ao uso e ocupação dos solos pelas atividades agropecuárias, o presente trabalho propõe-se a fazer uma análise preliminar, regional e qualitativa da adequação entre aptidão e uso das terras de acordo com os compartimentos morfopedológicos (CASTRO \& SALOMÃO, 2000) no município de Jataí, um dos três mais importantes do Sudoeste de Goiás. A partir dessa análise serão apontados possíveis conflitos ambientais em função dos usos e ocupação inadequados à capacidade dos solos, contribuindo nas tomadas de decisões e fornecendo subsídios para o planejamento local em termos de zoneamento.

\section{CARACTERIZAÇÃo DA ÁREA DE ESTUdO}

O município de Jataí localiza-se na microrregião Sudoeste de Goiás e possui uma área de aproximadamente 750.000 ha, fazendo divisa com os municípios de Aparecida do Rio Doce, Caçu, Caiapônia, Itarumã, Mineiros, Perolândia, Rio Verde e Serranópolis (Figura 1). De acordo com dados do IBGE (2006) e PNUD (2003), mesmo possuindo mais de $90 \%$ de sua população concentrada em área urbana, mais de $70 \%$ do seu território é rural.

A sede municipal está localizada nas coordenadas $17052^{\prime} 53^{\prime \prime}$ de latitude sul e $51^{\circ} 42^{\prime}$ 52 " de longitude oeste, a 708 metros de altitude em relação ao nível do mar. Essa dista $320 \mathrm{~km}$ de Goiânia e 528 km de Brasília, sendo cortada por importantes rodovias federais e estaduais, que fornecem saídas para o centro do estado de Goiás, Mato Grosso, Mato Grosso do Sul, Minas Gerais e São Paulo.

O município situa-se na Serra do Caiapó, que divide as bacias do Araguaia e do Parnaíba. Sua rede hidrográfica pertence à bacia do Paraná, sendo constituída de afluentes da margem direita do Parnaíba, como o Rio Claro e o Rio Doce, além dos rios Verde, Paraíso, Campo Belo, Felicidade e Córrego Jataí. A água que serve a cidade é captada no Rio Claro e distribuída à população após tratamento. 


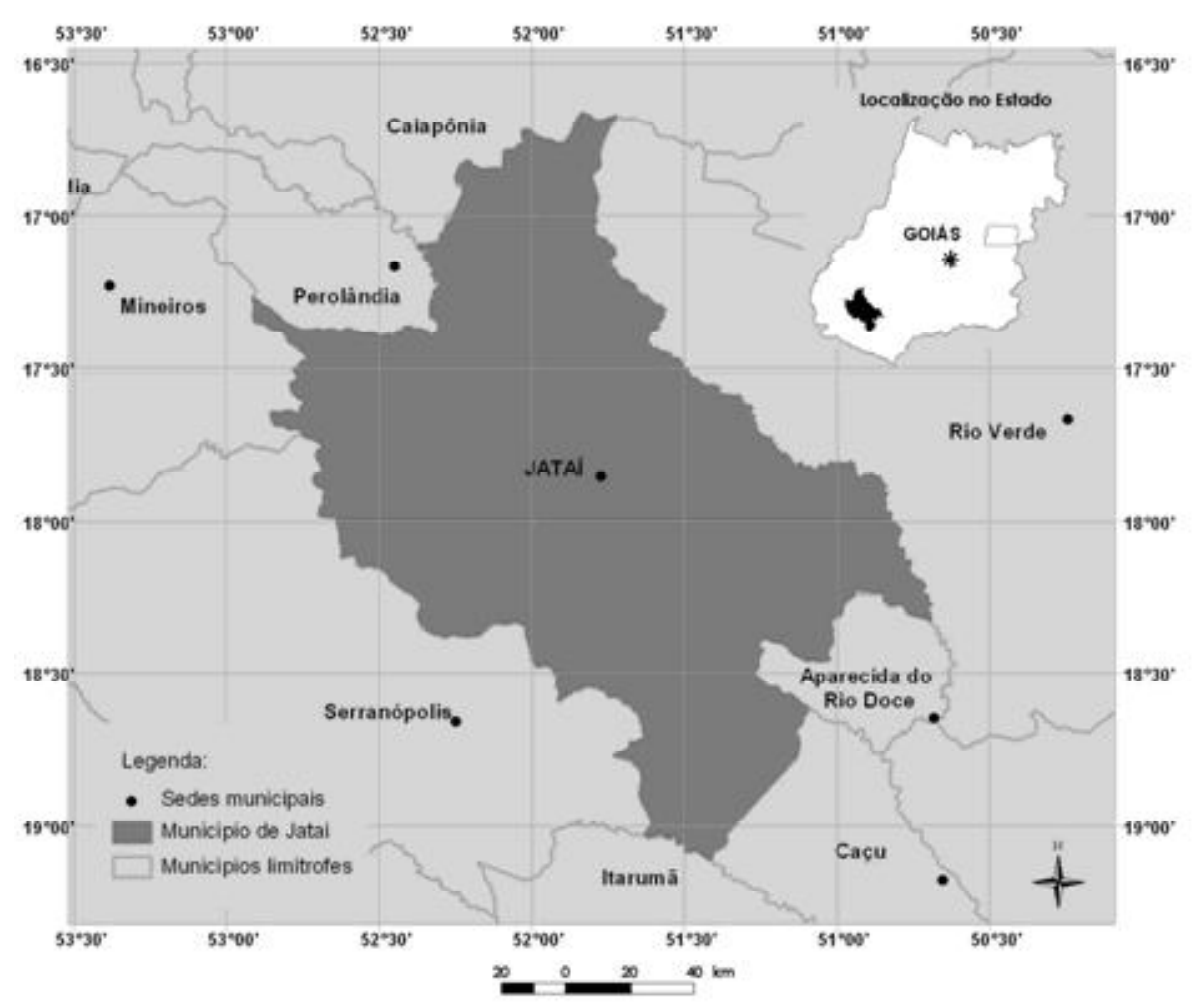

Figura 1 - Mapa de localização do município de Jataí

O clima é do tipo tropical mesotérmico, enquadrado na classe Aw definida por Köppen, que apresenta duas estações bem definidas por um regime diferenciado de chuvas. O maior índice pluviométrico ocorre entre outubro e abril, e o período de estiagem entre maio e setembro. 0 volume pluviométrico médio anual é de aproximadamente $1.800 \mathrm{~mm}$ e a temperatura média no inverno varia entre $10^{\circ} \mathrm{C}$ e $27^{\circ} \mathrm{C}$ e no verão varia entre $18^{\circ} \mathrm{C}$ e $35^{\circ} \mathrm{C}$, podendo chegar até $38^{\circ} \mathrm{C}$.

A vegetação original era caracterizada por diferentes fitofisionomias de cerrado: Cerradão, Cerrado sentido restrito, Campo Sujo, Campo Limpo e Mata de Galeria (EITEN, 1993; RIZZINI, 1979), mas essa atualmente encontra-se bastante fragmentada.
A geologia do município é marcada, principalmente, por areia, arenito e sedimentos areno-argilosos (na grande maioria), basalto e uma pequena mancha de siltito ao norte. Sua geomorfologia é representada por superfície de aplainamento em relevos tabulares da bacia do rio Paraná com dissecação fraca e média, além de pequenas manchas de planície aluvial com respectiva faixa aluvial. O relevo se apresenta plano a suavemente ondulado com a presença de formas tabulares em superfícies dissecadas, a leste e nordeste, destacando a Serra do Cafezal, a Serra do Rio Verde e a Serra do Caiapó. A hipsometria está distribuída entre as cotas 450 e 1050 metros, sendo as áreas mais altas a nordeste e noroeste, nas referidas serras. A declividade confirma que o município 
apresenta-se bastante plano, com $94,5 \%$ de sua área com declividade abaixo de $10 \%$.

Os solos da área são principalmente minerais, isto é, possuem baixo teor de carbono (EMBRAPA, 1997); profundos e muito profundos; argilosos ou de textura média. Segundo o mapa de solos do RADAMBRASIL (1982), seis classes podem ser encontradas: Nitossolos, Cambissolos, Neossolos, Gleissolos, Argissolos e Latossolos, cuja frequência é mostrada na Tabela 1. É notável o amplo predomínio dos Latossolos, os quais, juntamente com os Cambissolos e Argissolos, ultrapassam $90 \%$ da área total do município.

Convém ressaltar que os Latossolos prestam-se frequentemente ao uso intensivo com lavouras temporárias, devido aos atributos morfológicos e físico-hídricos que os caracterizam como estáveis e de elevada aptidão, ainda que necessitem de correção, adubação e mesmo irrigação (LEPSCH, 2002; RESENDE et al, 2002; SALOMÃO, 1999).

\section{Tabela 1 - Classes de solos por área}

\begin{tabular}{|c|c|c|}
\hline Classe de Solo & Área no munic ípio (ha) & $\mathbf{( \% )}$ \\
\hline Nitossolo & 9.505 & 1,26 \\
\hline Neossolo & 21.479 & 2,86 \\
\hline Gleissolo & 33.852 & 4,51 \\
\hline Argissolo & 48.045 & 6,40 \\
\hline Cambissolo & 93.103 & 12,41 \\
\hline Latossolo & 543.966 & 72,55 \\
\hline TOTAL & $\mathbf{7 4 9 . 9 5 1}$ ha & $\mathbf{1 0 0 \%}$ \\
\hline
\end{tabular}

De acordo com dados do IBGE (2006), a extensão das áreas de lavoura e pastagem são praticamente iguais, existindo um equilíbrio na sua distribuição ao longo do município. No contexto da produção agrícola, a análise da Produção Agrícola Municipal (IBGE, 2006) indica que a maioria das áreas de cultivo são destinadas à plantação de banana (entre as lavouras permanentes) e milho e soja (para as lavouras temporárias). Uma área pequena é destinada à cana-de açúcar (95 ha), no entanto seu rendimento médio é alto em relação às demais culturas.

\section{MATERIAIS E MÉTODOS}

Tendo em vista o objetivo geral proposto de identificar os conflitos no uso atual do solo com base na compartimentação morfopedológica para subsidiar o planejamento do uso do solo no município de Jataí, o presente trabalho foi dividido em quatro etapas metodológicas complementares descritas a seguir. São elas: compartimentação morfopedológica; avaliação da suscetibilidade à erosão linear; análise da capacidade de uso das terras; avaliação dos conflitos no uso aual.

\section{Compartimentação Morfopedológica}

Para melhor entendimento da paisagem local foi feita uma análise comparativa e associativa dos condicionantes físicos (geologia, geomorfologia, hipsometria e declividade) com as classes de solos encontradas no município.

Foram utilizados dados cartográficos, com corte 1:250.000, disponibilizados gratuitamente pelo Sistema Estadual de Estatística e de Informações Geográficas de Goiás - SIEG (2008), são eles: geologia, geomorfologia e solos (proveniente do mapeamento original do RADAMBRASIL, 1982). Os mapas de hipsometria e declividade foram elaborados no programa ENVI 4.3 a partir de dados do Modelo Digital de Terreno - MDT do projeto intitulado Shuttle Radar Topography Mission - SRTM, com resolução de 90 metros, disponibilizado gratuitamente pela NASA (2007).

Além dos dados citados, a compartimentação morfopedológica baseou-se, ainda, na análise de um mosaico de imagens de satélite elaborado no programa ENVI 4.3 a partir de cinco cenas do sensor CBERS 2, instrumento $C C D$, disponibilizadas gratuitamente pelo Instituto Nacional de Pesquisas Espaciais - INPE (2008), a saber:
1.Órbita/Ponto 161/119, de 03/07/2007;
2.Órbita/Ponto 160/120, de 06/07/2007;
3.Órbita/Ponto 160/121, de 06/07/2007;
4.Órbita/Ponto 161/121, de 03/07/2007;
5.Órbita/Ponto 161/120, de 03/07/2007. 
A partir da superposição cartográfica, no programa ArcGis 9.3, dos mapas de geologia, geomorfologia, hipsometria, declividade, solos e do mosaico de imagens do sensor CBERS 2, foi possível a identificação de unidades homogêneas no que se refere aos aspectos fisiográficos dentro do município, chamadas aqui de Compartimentos Morfopedológicos (MP).

Os critérios para a definição de cada compartimento variaram de acordo com as características físicas analisadas em conjunto. De forma geral, procurou-se utilizar dos divisores de água e da rede de drenagem como limites dos MP, mas, em alguns casos, prevaleceram os limites físicos de condicionantes específicos predominantes de cada área.

Com os limites dos MP definidos, foram traçados perfis topográficos representativos de cada um dos compartimentos com a indicação dos respectivos tipos de solos neles contidos.

\section{Suscetibilidade à Erosão Linear}

Baseado em Salomão (1999), foram definidas as classes de erodibilidade nas quais estão inseridos os solos encontrados no município de Jataí (Tabela 2). A partir desses dados foi elaborado, no programa ArcGis 9.3, o mapa de erodibilidade.

\section{Tabela 2 - Classes de erodibilidade por classes de solos existentes no município de Jataí}

\begin{tabular}{|l|l|}
\hline Classes de Erodibilidade & Unidades Pedológicas \\
\hline 1. Muito Alta & Cambissolos, Neossolos Quartzarênicos e Nitossolos \\
\hline 2. Alta & Argissolos (não abruptos de tex tura média/argilosa e mé dia) \\
\hline 3. Média & Argissolos (de textura argilosa) \\
\hline 4. Baixa & Latossolos \\
\hline 5. Nula & Gleissolos \\
\hline
\end{tabular}

Fonte: Adaptado de Salomão (1999)

O cruzamento dos dados de erodibilidade, declividade e solos, no programa ArcGis 9.3, permitiu a elaboração do mapa de suscetibilidade à erosão linear com base nos critérios definidos por Salomão (1999):

- Extremamente suscetível - Classe I;

- Muito suscetível - Classe II;

- Moderadamente suscetível - Classe III;

- Suscetível - Classe IV;

- Não suscetível - Classe V.

\section{Capacidade de Uso das Terras}

A classificação da capacidade de uso das terras teve como referência o "Sistema de Capacidade de Uso" proposto por Lepsch (1991), que estabeleceu categorias com base nos tipos e intensidade de uso, relacionados a seguir:

- Grupo A - Terras aptas a cultivos intensivos anuais, culturas perenes, pastagens e reflorestamentos, compreendendo as seguintes classes:

o Classe I - correspondem às terras cultiváveis sem problemas de erosão. Terrenos sem problemas especiais de conservação, podendo ser utilizados com qualquer tipo de cultura.

- Classe II - são as terras cultiváveis com problemas simples de erosão (ravinas e sulcos), podendo ser utilizados com qualquer tipo de cultura, porém exigindo práticas simples de controle de erosão.

- Classe III - são as terras cultiváveis apenas ocasionalmente com problemas de erosão e conservação; mais indicados a pastagens e culturas perenes e, eventualmente, a culturas anuais, 
porém exigindo práticas intensivas mecanizadas de controle de erosão.

o Classe IV - são as terras cultiváveis apenas ocasionalmente, onde os terrenos apresentam problemas complexos de conservação; indicados para pastagens e culturas perenes.

- Grupo B - Terras impróprias para cultivos, mas aptas para pastagens, compreendendo as seguintes classes:

- Classe V - Sem problemas de erosão e conservação, mas exigindo técnicas especiais de cultivo, por se constituírem de solos mal drenados.

o Classe VI - Problemas de conservação, parcialmente favoráveis à ocupação por pastagens, sendo mais apropriados para reflorestamento.

- Classe VII - Problemas complexos de conservação, indicados para preservação ou reflorestamento.

- Grupo C - Terras indicadas somente para a preservação, compreendendo a classe:

o Classe VIII - corresponde às áreas de proteção ambiental, onde os terrenos apresentam problemas complexos de conservação; indicados para preservação.

Tomando-se como base os trabalhos de Salomão (1999) e Ribeiro e Salomão (2003), foram relacionadas as classes de suscetibilidade à erosão linear com as classes de capacidade de uso das terras definidas por Lepsch (1991) no município de Jataí, mostradas na Tabela 3.

\section{Tabela 3 - Relação entre suscetibilidade à erosão linear e capacidade de uso das terras do município de Jataí.}

\begin{tabular}{|l|l|}
\hline Suscetibilidade à erosão linear (Salomão, 1999) & Capacidad e de uso das terras (Lepsch, 1991) \\
\hline Classe I - Extremamente suscetível & Classes V II e V III \\
\hline Classe II - Muito suscetível & Classe VI \\
\hline Classe III - Moderadamente suscetível & Classe IV \\
\hline Classe IV - Suscetível & Classe III \\
\hline Classe V - Não-suscetível & Classes I, II e V \\
\hline
\end{tabular}

A partir do cruzamento desses dados no programa ArcGis 9.3, foi possível elaborar o mapa de capacidade das terras de cada MP do município de Jataí.

\section{Conflitos no Uso Atual do Solo}

Para avaliação da existência de conflitos no uso atual do solo no município de Jataí, primeiramente foi analisado o mapa de uso do solo elaborado em 2006 pela Secretaria de Planejamento e Desenvolvimento de Goiás. Como subsídio foram utilizados dados sobre a estrutura fundiária do município fornecidos pela Secretaria de Agricultura do Estado de Goiás com base no ano de 1995, além da observação visual do mosaico de imagens de satélite elaborado anteriormente.
O diagnóstico de conflitos do uso do solo existentes em cada um dos MP foi feito a partir do cruzamento, no programa ArcGis 9.3, da suscetibilidade à erosão/capacidade das terras e uso atual do solo. Esse cruzamento buscou identificar as áreas nas quais o uso atual do solo é incompatível com a suscetibilidade à erosão e capacidade das terras.

Os resultados obtidos nas três etapas metodológicas anteriores, embasaram a definição de áreas de conflito no uso atual do solo de acordo com as características físicas predominantes em cada MP. Dessa forma, foi elaborado, no programa ArcGis 9.3, o mapa de conflitos no uso atual de cada MP do município de Jataí, classificados como nulo, baixo, médio e alto conflito. 


\section{RESULTADOS}

A observação dos condicionantes físicos indicaram as diretrizes para a compartimentação morfopedológica do município de Jataí. Os critérios para a definição dos limites dos MP variaram de acordo com as características físicas do município associadas entre si, que permitiram a definição de cinco compartimentos bem definidos e de fácil visualização, como mostra a Tabela 4 e o mapa de compartimentação morfopedológica (Figura 2).

Tabela 4 - Critérios para definição dos compartimentos morfopedológicos e suas respectivas áreas.

\begin{tabular}{|c|l|c|c|}
\hline MP & \multicolumn{1}{|c|}{ Critérios para Definição } & Área & $\%$ \\
\hline MP-I & $\begin{array}{l}\text { Topo de chapada, litologia e geomorfologia uniformes com inclusão de solos } \\
\text { de mesma composição e continuidade topográfica (do topo à vertente da } \\
\text { encosta). Área de recarga de aquíferos no município. }\end{array}$ & 157.161 & 22 \\
\hline MP-II & $\begin{array}{l}\text { A área apresenta-se uniforme com relevo movimentado e presença da mesma } \\
\text { classe de solo ao longo de todo compartimento. }\end{array}$ & 91.004 & 12 \\
\hline MP-III & Topo de chapada com nascentes. Área de re carga de aquífero do município. & 118.319 & 16 \\
\hline MP-IV a & $\begin{array}{l}\text { Relevo movimentado com presença da mesma cla sse de solo ao longo da área. } \\
\text { Geomorfologia uniforme. O limite é exatamente o divisor de água. }\end{array}$ & 78.517 & 10,5 \\
\hline MP-IV b & $\begin{array}{l}\text { Relevo movimentado com presença da mesma cla sse de solo ao longo da área. } \\
\text { Geomorfologia uniforme. Litologia diferenciada da unidade anterior. }\end{array}$ & 36.858 & 4 \\
\hline MP-V & $\begin{array}{l}\text { Grande vale com classes litológicas, geomorfológicas e pedológicas } \\
\text { condizentes e uniformes. }\end{array}$ & 268.142 & 35,5 \\
\hline \multicolumn{1}{|c|}{ Total } & $\mathbf{7 5 0 . 0 0 0}$ & $\mathbf{1 0 0}$ \\
\hline
\end{tabular}

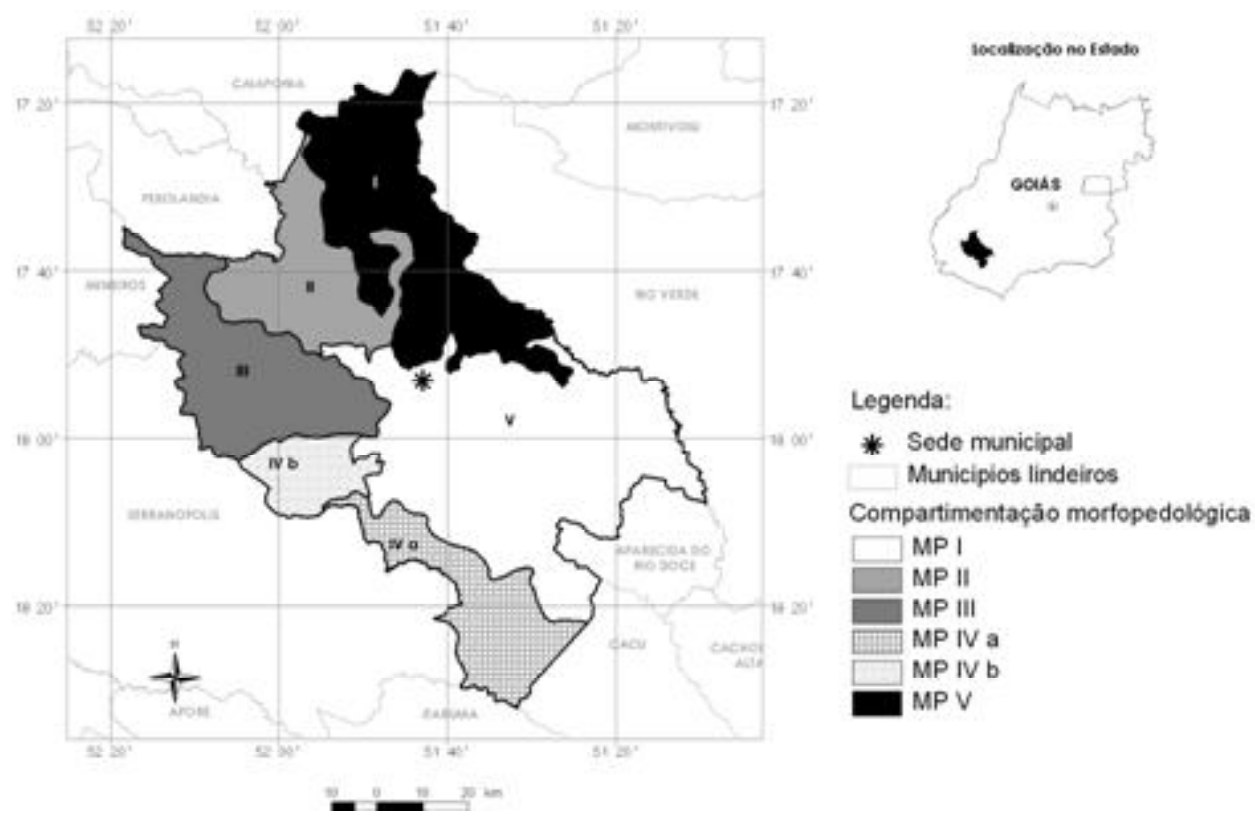

Figura 2 - Mapa de compartimentação geomorfológica do município de Jataí 
Uma análise visual pode ser feita ao comparar-se os condicionantes utilizados com os limites definidos de cada compartimento. Essa observação confirma a homogeneidade em relação aos condicionantes existentes em cada um dos compartimentos individualmente (Figura 3 ).

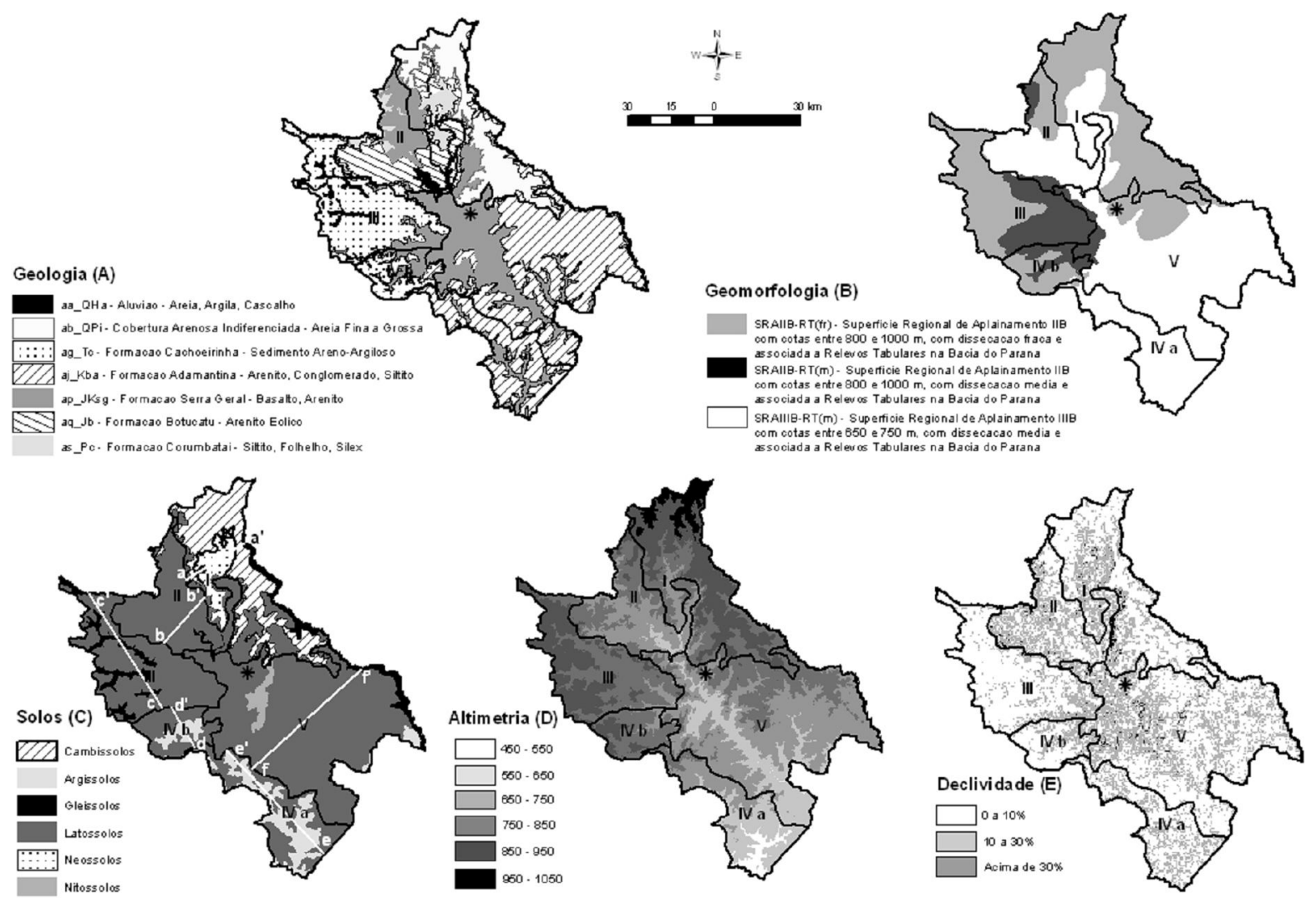

Figura 3 - Comparação dos mapas geológico (A), geomorfológico (B), pedológico (C), hipsométrico (D) e de declividade (E) com os compartimentos morfopedológicos

Perfis topográficos dos eixos mais representativos, indicados na Figura 3C, apresentam a localização dos tipos de solos característicos de cada compartimento (Figuras 4 a 9).

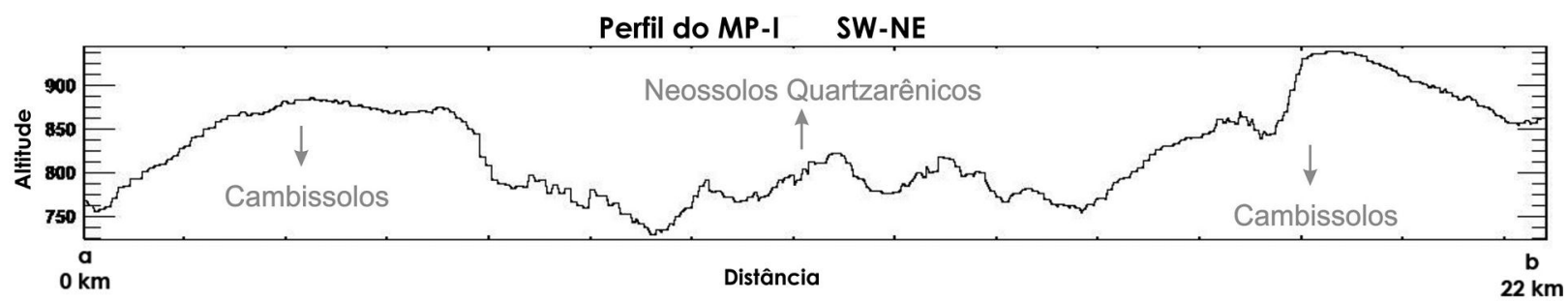

Figura 4 - Perfil topográfico do MP I (a-a') 
No MP I os solos predominantes são os Cambissolos (nas área mais suavizadas dos interflúvios mais elevados), seguidos dos Neossolos Quartzarênicos nas áreas mais declivosas dos interflúvios mais baixos.

Perfil do MP-II SW-NE

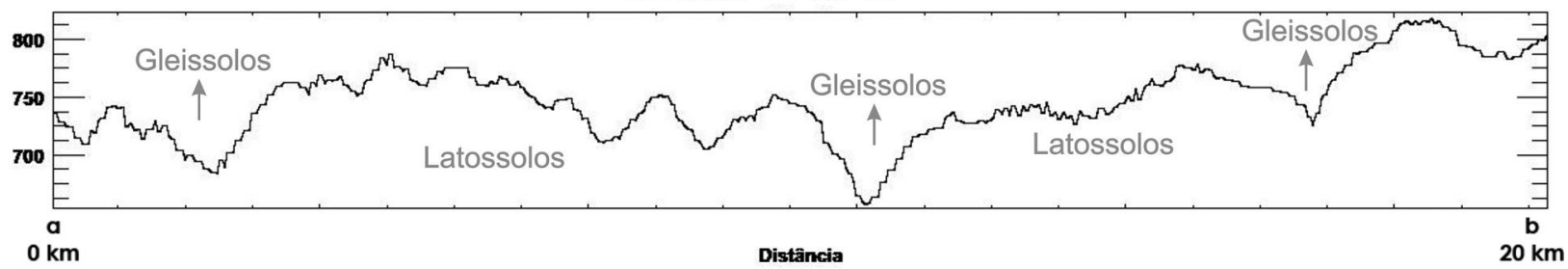

Figura 5 - Perfil topográfico do MP II (b-b')

O MP II é caracterizado, na escala adotada, por Latossolos. No perfil topográfico, que mostra um intervalo de pouco mais de 100 metros de altitude entre a área mais baixa e a mais alta, pode-se observar áreas de provável existência de solos relacionados a drenagens (Gleissolos, por exemplo), como o Rio Claro, mas que no mapa de solos utilizado não foram mapeados nessa escala de trabalho.

Perfil do MP-III SE-NW

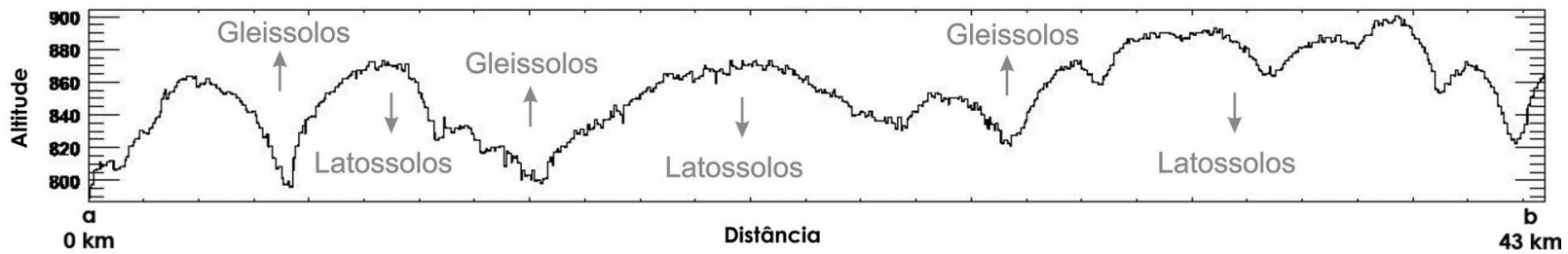

Figura 6 - Perfil topográfico do MP III (c-c')

O perfil do MP III indica claramente a diferença de relevo na localização dos Latossolos (áreas mais altas e planas) e dos Gleissolos (fundos de vales).
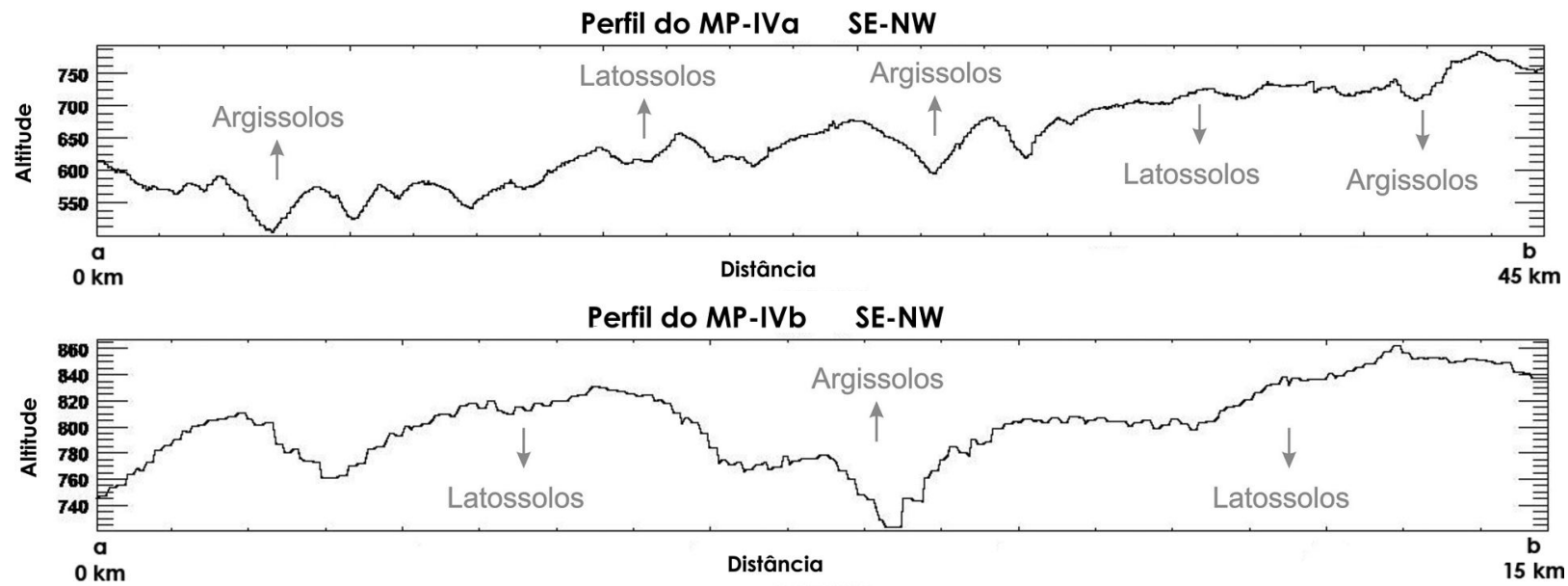

Figuras 7 e 8 - Perfil topográfico do MP IV a (d-d') e b (e-e') 
No subcompartimento IVa pode-se observar a existência de Latossolos nas áreas aplainadas e Argissolos nas vertentes. O perfil se mostra um pouco mascarado (parecendo que as vertentes são bastante íngremes), uma vez que representa uma área de $45 \mathrm{~km}$, sendo isso efeito da distorção da escala.

Assim como no compartimento anterior, no MP-IVb pode-se observar a existência de
Latossolos nas áreas aplainadas e Argissolos nas vertentes. O que os difere é a altitude encontrada em cada um dos subcompartimentos.

O MP V é caracterizado pela ocorrência de Latossolos e, assim como o MP-IVa, o perfil também se mostra mascarado, uma vez que representa uma área de $47 \mathrm{~km}$. Este perfil mostra um intervalo de aproximadamente 200 metros de altitude entre a área mais baixa e a mais alta

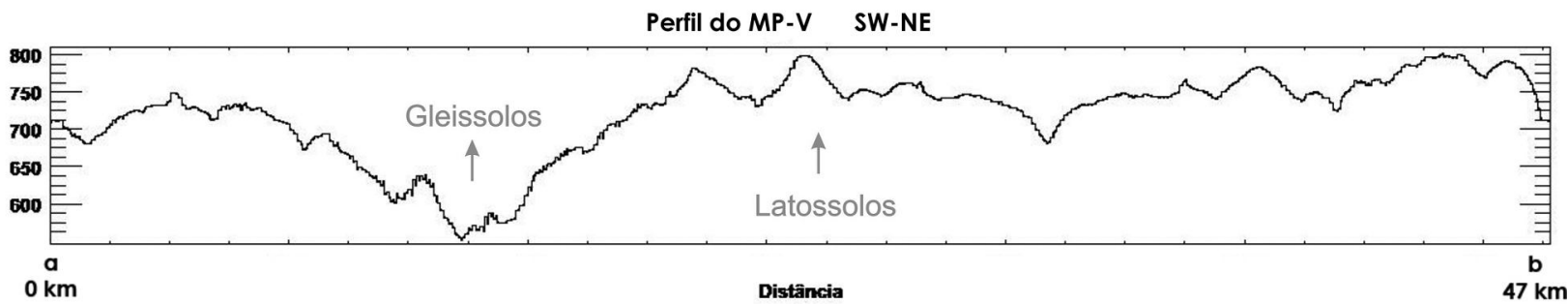

Figura 9 - Perfil topográfico do MP V ( $\left.f-f^{\prime}\right)$

e, assim como o MP-II, pode-se observar áreas de provável existência de solos relacionados a drenagens (Gleissolos, por exemplo), como o vale do Rio Claro, mas no mapa de solos não foram mapeados nessa escala de trabalho.

A partir desses resultados foi elaborado o mapa de erodibilidade (Figura 10), que mostra que a maior parte do município está inserida na classe de baixa erodobilidade. Porém, deve ser dada atenção aos compartimentos I e IVa e b, os quais, em função dos solos existentes (Cambissolo, Neossolo Quartzarênico e Argissolo), estão inseridos na classe de erodibilidade muito alta.

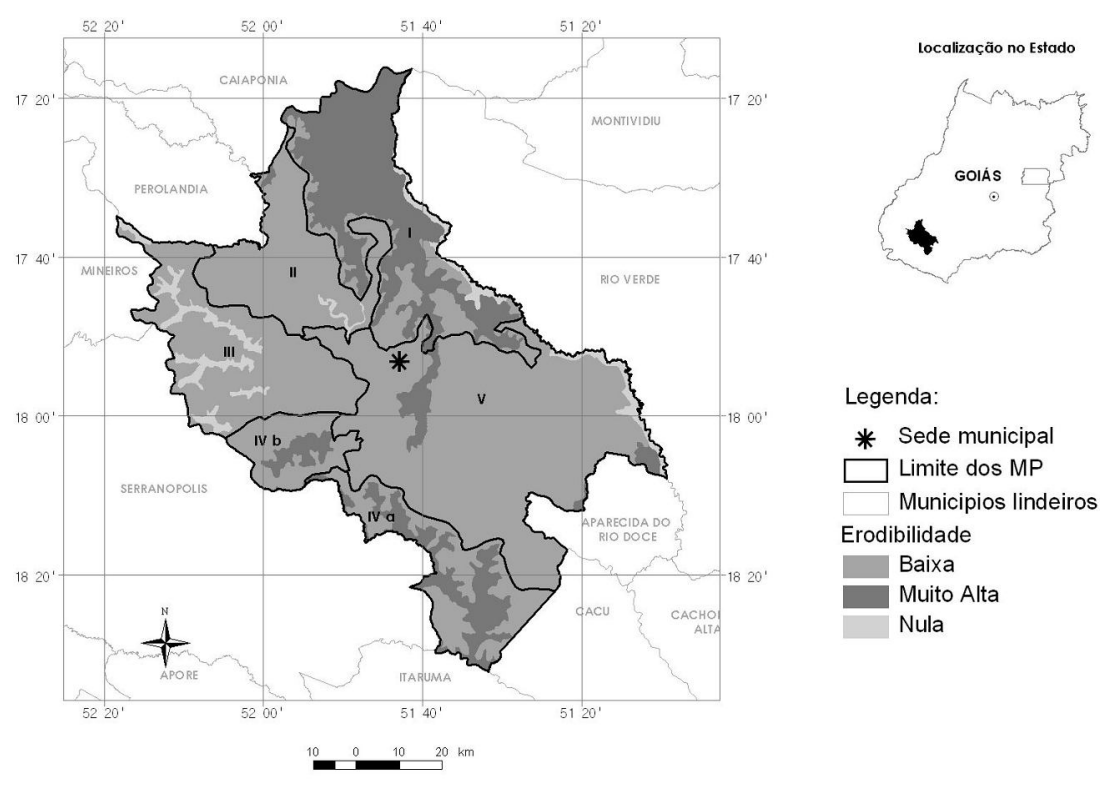

Figura 10 - Mapa de erodibilidade do município de Jataí 
A análise da erodibilidade juntamente com a declividade e a pedologia permitiu a seguinte caracterização regional dos MP de acordo com as classes de suscetibilidade à erosão linear definidas por Salomão (1999)

(Tabela 5, Figura 11):

\section{Tabela 5 - Suscetibilidade à erosão Linear dos MP de Jataí}

\begin{tabular}{|c|l|}
\hline MP & \multicolumn{1}{c|}{ Suscetibilidade à Erosão Linear Predominante } \\
\hline MP-I & $\begin{array}{l}\text { - Topo da chapada (Cambissolos): Classe IV - Suscetível: Mesmo tendo alta } \\
\text { erodibilidade devido ao tipo de solo ali existente, a declividade é muito baixa (menor } \\
\text { que 10\%), o que não permite a concentração de fluxos d'á gua. } \\
\text { - Vertentes com declividade acima de 20\% (Neossolos Quartzarênicos): Classe II - } \\
\text { Muito suscetível. }\end{array}$ \\
\hline MP-II & $\begin{array}{l}\text { - Classe III - Moderada mente suscetível: o compartimento é completamente tomado } \\
\text { por Latossolos, com dissecação média. }\end{array}$ \\
\hline MP-III & $\begin{array}{l}\text { - Topo da chapada (Latossolos): Classe III - Moderadamente suscetível: o } \\
\text { compartimento é constituído por Latos solos. } \\
\text { - Margens de cursos d'água (Gleissolos): Classe V - Não suscetível. }\end{array}$ \\
\hline MP-IV a & $\begin{array}{l}\text { - Terço médio das vertentes (Argissolos): Classe II - Muito suscetível: Isso acontece } \\
\text { porque os Argissolos estão localizados na vertente. } \\
\text { - Áreas planas: Classe III - Moderadamente suscetível: áreas dos Latos solos. }\end{array}$ \\
\hline MP-IV b & $\begin{array}{l}\text { - Topo da chapada (Latossolos): Classe III - Moderadamente suscetível: o } \\
\text { compartimento é constituído por Latossolos. } \\
\text { - Terço médio das vertentes (Argissolos): Classe II - Muito suscetível: Isso acontece } \\
\text { porque os Argissolos estão localizados na vertente. }\end{array}$ \\
\hline MP-V & $\begin{array}{l}\text { - Classe III - Moderada mente suscetível: o compartimento é completa mente tomado } \\
\text { por Latossolos, além de pequena mancha de Nitossolo, com dissecação fraca. }\end{array}$ \\
\hline
\end{tabular}
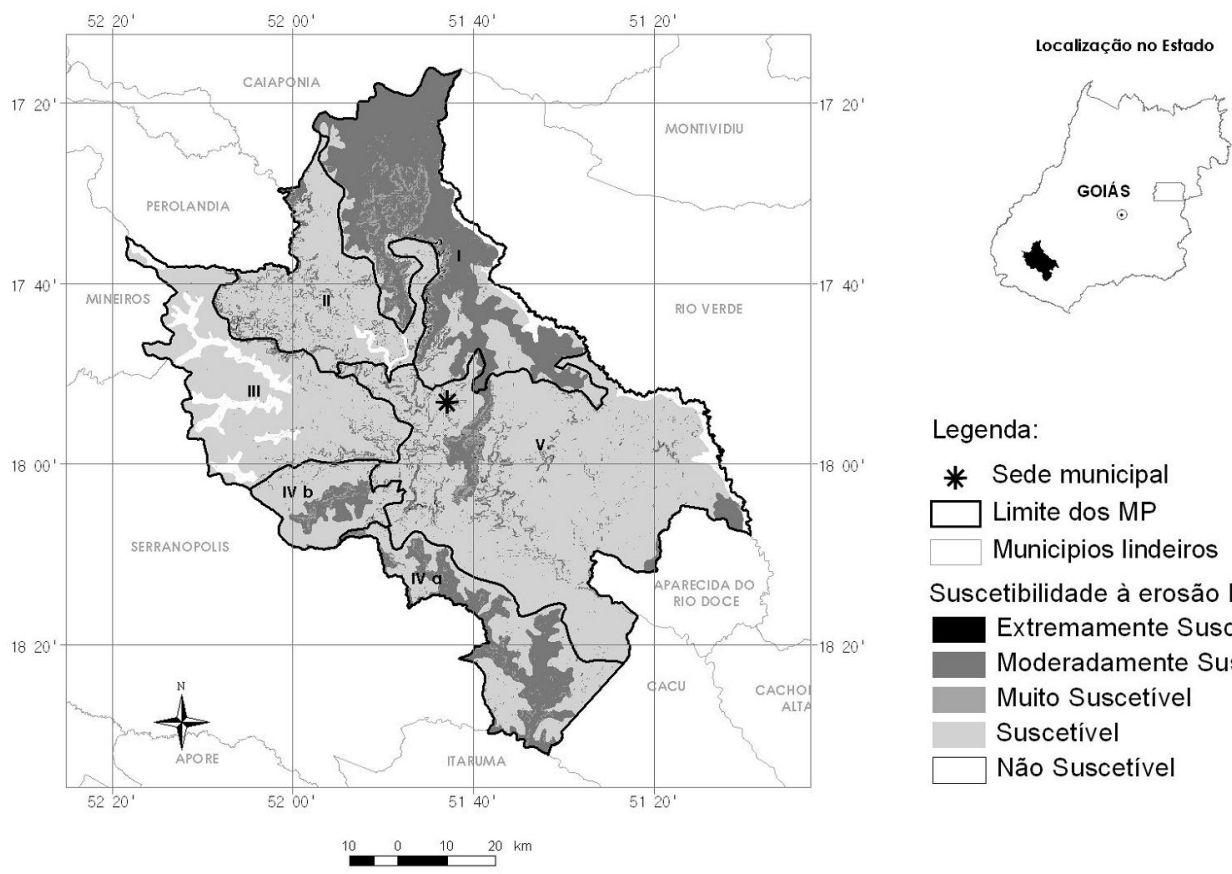

Legenda:

* Sede municipal

Limite dos MP

Municipios lindeiros

Suscetibilidade à erosão linear

Extremamente Suscetível Moderadamente Suscetível Muito Suscetível

Suscetível

Não Suscetível

Figura 11 - Mapa de suscetibilidade à erosão Linear do município de Jataí 
A partir dos dados de suscetibilidade à erosão linear foi definida a capacidade de uso da terra de acordo com as características individuais de cada MP (Tabela 6; Figura 12).

\section{Tabela 6 - Capacidade de Uso das Terras de Jataí}

\begin{tabular}{|c|l|}
\hline MP & \multicolumn{1}{c|}{ Capacidade de Uso das Terras } \\
\hline MP-I & $\begin{array}{l}\text { - Topo: Classe III: são as terras cultiváveis apenas ocasionalmente, com problemas de ero ão e } \\
\text { conservação; mais indicadas a pastagens e culturas per enes e, eventualmente, a culturas anuais, porém } \\
\text { exigindo práticas intensivas mecanizadas de controle de ero são. } \\
\text { - Vertentes: Clas se s VII e VIII: Problemas complex os de conservação, indicadas pa ra preservação ou } \\
\text { para reflores tamento. }\end{array}$ \\
\hline MP-II & $\begin{array}{l}\text { - Classe IV: são as terras cultiváve is apenas ocasionalmente, onde os terrenos aprese nta m problemas } \\
\text { comple xos de conservação; indicadas para pastagens e culturas perenes. }\end{array}$ \\
\hline MP-III & $\begin{array}{l}\text { - Classe II: são as terras cultiváveis com problemas simples de erosão (ravinas e sulcos), podendo ser } \\
\text { utilizadas com qualquer tipo de cultura, porém exigindo prática s simples de controle de er osã o. } \\
\text { - Cur sos d'água: Classe VIII: corresponde às áreas de proteção ambiental, onde os te rrenos } \\
\text { apresentam problemas complex os de conservação; indicados para preservação. }\end{array}$ \\
\hline MP-IV a & $\begin{array}{l}\text { - Classe VI: Problemas de conservação, parcialmente favoráveis à ocupação por pastagens, sendo mais } \\
\text { apropriadas para re flore stamento. }\end{array}$ \\
\hline MP-IV b & $\begin{array}{l}\text { - Classe II: são as terras cultiváveis com problemas simples de erosão (ravinas e sulcos), podendo ser } \\
\text { utilizadas com qualquer tipo de cultura, porém exigindo práticas simples de controle de erosão. }\end{array}$ \\
\hline MP-V & $\begin{array}{l}\text { - Classe II: são as terras cultiváveis com problemas simples de erosão (ravinas e sulcos), podendo ser } \\
\text { utilizados com qualquer tipo de cultura, porém exigindo práticas simples de controle de erosão. }\end{array}$ \\
\hline
\end{tabular}
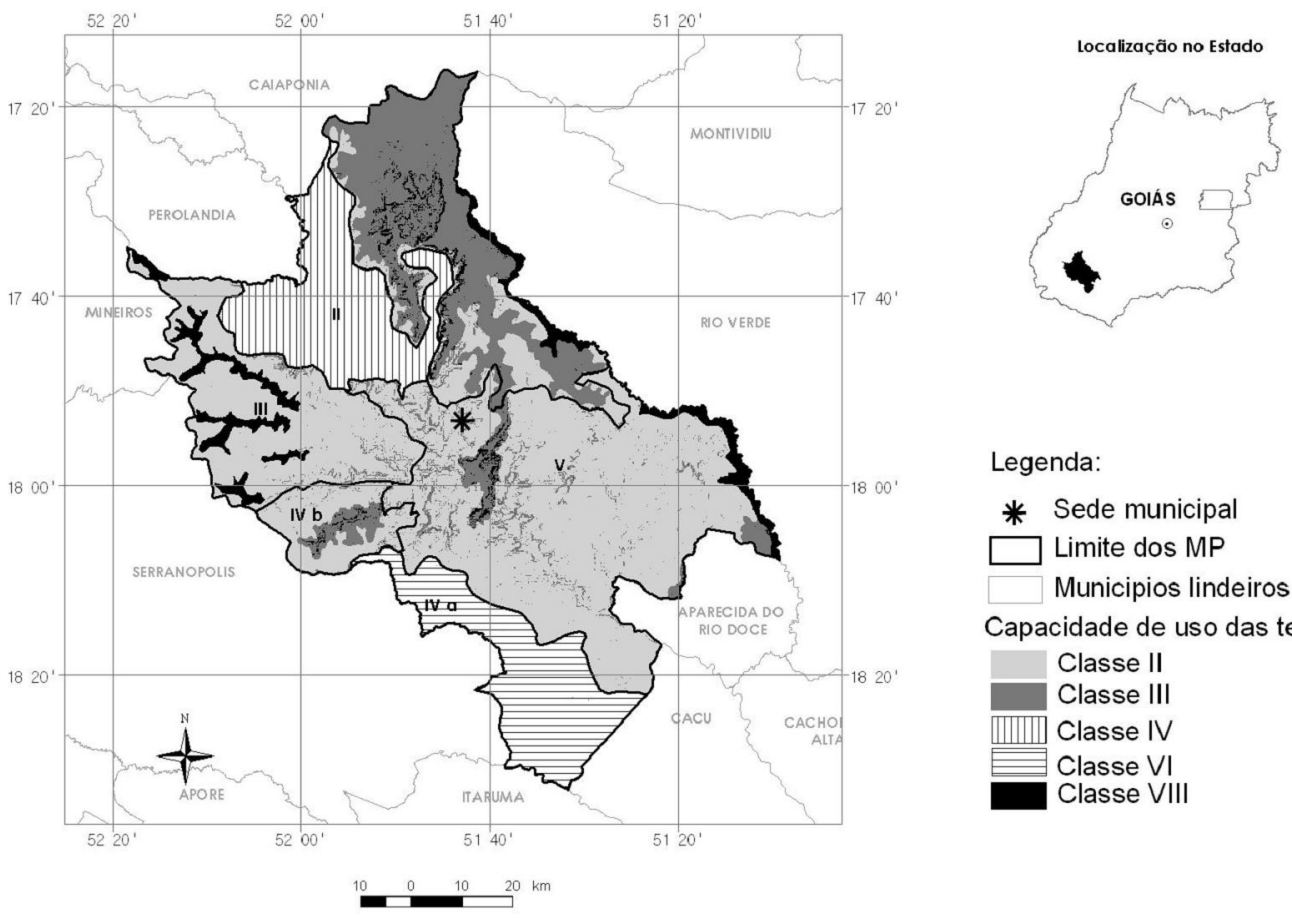

Legenda:

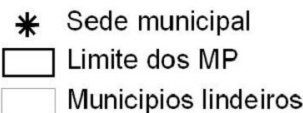

Capacidade de uso das terras

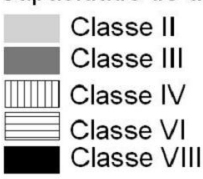

Figura 12 - Mapa de capacidade de uso das terras do município de Jataí 
Algumas ressalvas devem ser feitas no presente estudo no que diz respeito à correlação feita por Salomão (1999) e Ribeiro e Salomão (2003) entre as classes de suscetibilidade à erosão linear e as classes de capacidade de uso da terra proposta por Lepsch (1991). A primeira é quando os referidos autores correlacionam a Classe III de suscetibilidade à erosão à classe IV de capacidade de uso da terra. No caso específico do presente estudo, os compartimentos MP-III, MP-IVb e MP-V possuem a maioria de suas áreas ocupadas por Latossolos em áreas de baixa declividade, o que permite o seu uso por lavouras temporárias e não apenas para pastagens e culturas perenes. Dessa forma, os citados compartimentos foram enquadrados na Classe II de capacidade de uso da terra. Além dessa, no que se refere ao MPIVb, mesmo tendo incidência de Argissolos na região de maior declividade (conforme indica o perfil do compartimento - Figura 9), de acordo com a imagem de satélite são os Latossolos que estão ocupados por agricultura, o que não gera conflitos de uso atual em relação aos condicionantes ambientais.

O mapa de uso do solo (Figura 13) mostra que a maior parte do município é ocupada por lavouras e pastagens, confirmando que, principalmente a região sul-sudeste, além de pequena área ao norte, são especializadas em pecuária, enquanto no restante do município predomina a agricultura. Corroborando com isso, os dados sobre a estrutura fundiária de 1996 (Tabela 7) mostram a predominância de grandes propriedades rurais (acima de 1000 ha), que correspondem a quase metade $(48,4 \%)$ da área total de propriedades existentes em Jataí. Essas somadas às propriedades com tamanho entre 500 e 1000 ha, alcançam cerca de $70 \%$ do território.

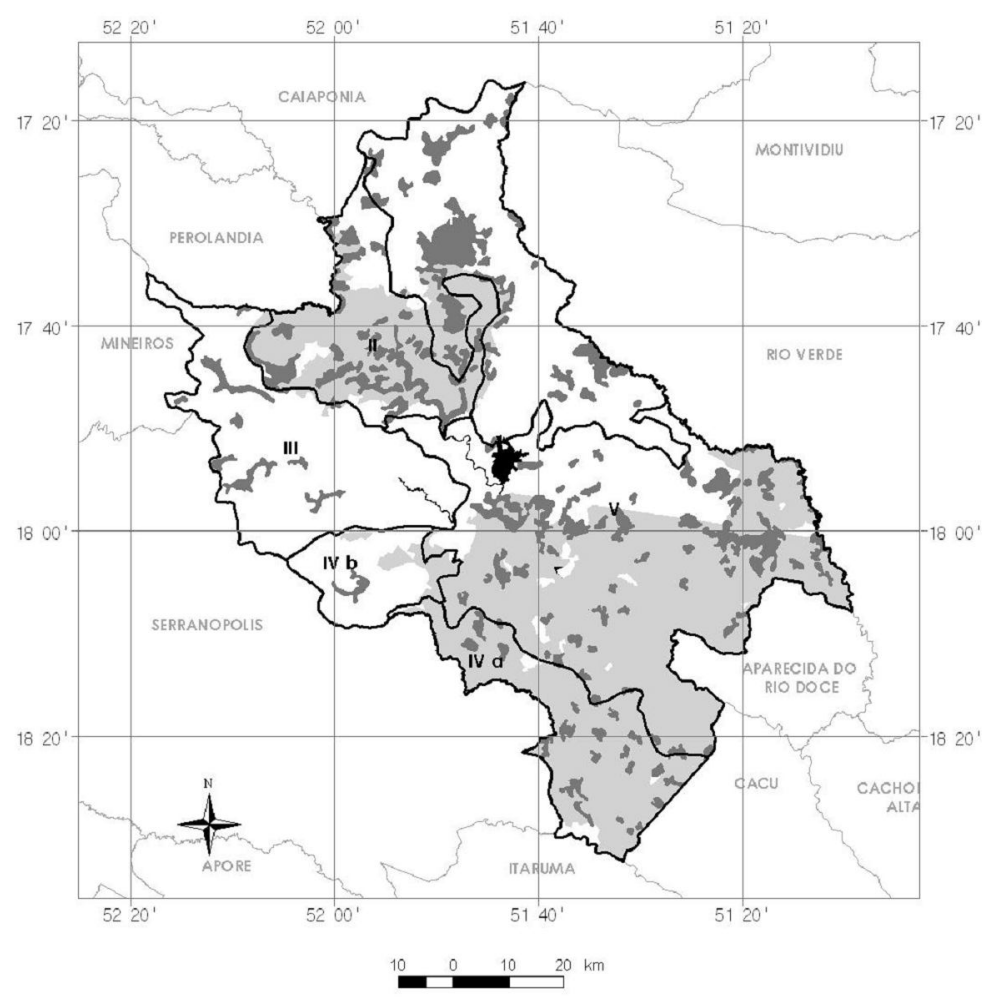

Legenda:

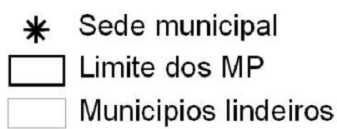

Uso do solo

\begin{tabular}{|l}
$\square$ Agricultura \\
Pastagem \\
Vegetação nativa \\
Área urbana
\end{tabular}

Figura 13 - Uso do Solo - SIEG, 2008 
Tabela 7 - Estrutura Fundiária do município de Jataí

\begin{tabular}{|l|c|c|c|}
\hline Classe das Propriedades & Número de Estabelecimentos & Área (ha) & \% \\
\hline 0 a menos de 20 ha & 174 & 1.622 & 0,251299 \\
\hline 20 a menos de 50 ha & 304 & 9.992 & 1,548079 \\
\hline 50 a menos de 100 ha & 198 & 14.981 & 2,321034 \\
\hline 100 a menos de 200 ha & 242 & 36.680 & 5,682901 \\
\hline 200 a menos de 500 ha & 384 & 126.513 & 19,6009 \\
\hline 500 a menos de 1000 ha & 203 & 143.167 & 22,18113 \\
\hline Mais de 1000 ha & 165 & 312.490 & 48,41466 \\
\hline TOTAL & $\mathbf{1 . 6 7 0}$ & $\mathbf{6 4 5 . 4 4 5}$ & $\mathbf{1 0 0}$ \\
\hline
\end{tabular}

Fonte: IBGE: Censo Agropecuário 1995/1996; SEAGRO/GOIÁS, 1996.

A análise do uso atual juntamente com a estrutura fundiária permitiu inferir os usos predominantes de cada compartimento (Tabela 8 ), indicando uma setorização das atividades agropecuárias. Assim, pode-se observar que os compartimentos localizados ao norte do município são especializados na agricultura de grande porte (com exceção do MP-II) e os localizados ao sul (especialmente o MP-V, que ocupa a maior área dessa região) na pecuária.

\section{Tabela 8 -Uso Atual do Solo em Jataí}

\begin{tabular}{|c|l|}
\hline MP & \multicolumn{1}{|c|}{ Uso Atual do Solo Predominante } \\
\hline MP-I & $\begin{array}{l}\text { Lavoura te mporária onde ocorre a predominância das grandes e médias propriedades altamente } \\
\text { tecnificadas que se utilizam de avanços tecnológicos de produção agrícola em lar ga escala, como é } \\
\text { o caso das lavouras de soja e milho. }\end{array}$ \\
\hline MP-II & Agricultura e pecuária restrita \\
\hline MP-III & $\begin{array}{l}\text { Lavoura te mporária onde ocorre a predominância das grandes e médias propriedades altamente } \\
\text { tecnificadas que se utilizam de avanços tecnológicos de produção agrícola em lar ga escala, como é } \\
\text { o caso das lavouras de soja e milho. }\end{array}$ \\
\hline MP-IV a & Agricultura e pecuária restrita \\
\hline MP-IV b & $\begin{array}{l}\text { Lavoura te mporária onde ocorre a predominância das grandes e médias propriedades altamente } \\
\text { tecnificadas que se utilizam de avanços tecnológicos de produção agrícola em lar ga escala, como é } \\
\text { o caso das lavouras de soja e milho. }\end{array}$ \\
\hline MP-V & Pecuária e Vegetação nativa \\
\hline
\end{tabular}

Dado o exposto, considerando as correlações entre as classes de suscetibilidade à erosão/capacidade das terras e os usos predominantes de cada MP, foram definidos os níveis de conflitos no uso atual, apresentados a seguir e ilustrados na Figura 14:

- MP-I - Conflito Médio: composto por Cambissolos no topo da chapada. Mesmo com declividade muito baixa (abaixo de $10 \%$ ), sua capacidade de uso é restritiva para lavouras temporárias. Já na área dos Neossolos Quartzarênicos, de alta declividade, o uso atual (vegetação preservada) é condizente com os condicionantes ambientais, uma vez que são solos frágeis e necessitam de preservação.

- MP-II - Conflito Baixo: a análise do uso atual mostra que a área é composta por propriedades com agricultura de pequeno porte e pastagens, o que condiz com a capacidade de uso, já que é a região mais declivosa do município composta por Latossolos. O problema é que, se os solos 
não forem manejados com cuidado, em áreas de declive podem apresentar erosão Linear.

- MP-III - Conflito Baixo: composto em sua imensa maioria por Latossolos, que são moderadamente susceptíveis à erosão, mas a área é bastante plana, o que minimiza o risco mesmo com culturas temporárias.

- MP-IVa - Conflito Médio: possui grande quantidade de Argissolos, o que o faz ser muito susceptível à erosão. Por esse motivo, suas terras são da classe VI, ou seja, parcialmente favoráveis à ocupação por pastagens, sendo mais apropriados para reflorestamento. Isso não ocorre no compartimento, que é tomado por agricultura de pequeno porte e pastagens, o que exige atenção especial ao pisoteio do gado, e quase não apresenta vegetação nativa ou de reflorestamento, com exceção das áreas de reserva legal, que representam pequena parte de cada propriedade.

- MP-IVb - Conflito Baixo: como dito anteriormente, mesmo tendo incidência de Argissolos, são os Latossolos que estão ocupados por agricultura, o que não gera conflitos de uso atual em relação aos condicionantes ambientais.

- MP-V - Conflito Baixo: composto por Latossolos em área bastante plana com uso predominante de pastagens, além de vegetação nativa. Vale aqui a mesma recomendação do MP-II, a qual enfatiza o problema de erosão nos Latossolos, caso não sejam manejados com cuidado.

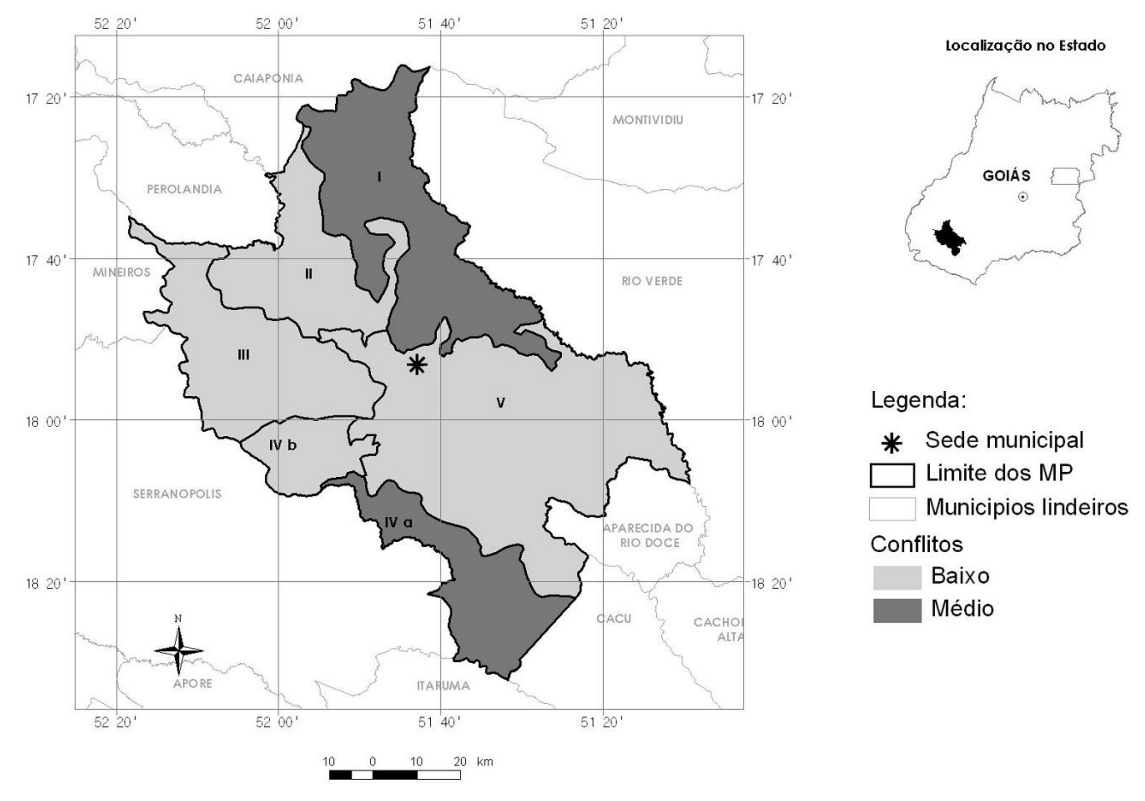

Figura 14 - Conflitos no Uso Atual do Solo

A Tabela 9 sintetiza as características dos MP do município de Jataí, possibilitando comprovar o predomínio do nível de conflito baixo para a maioria deles, e médio apenas para os compartimentos I e IVa, devido, principalmente, à prática agrícola em áreas que apresentam restrições para esse tipo de atividade. Contudo, considerando-se a escala adotada, é possível que os conflitos sejam maiores, só percebidos com detalhamento da análise. 
Tabela 9 - Tabela-síntese dos MP de Jataí com as classes predominantes de cada condicionante físico ${ }^{1}$

\begin{tabular}{|c|c|c|c|c|c|c|c|}
\hline \multicolumn{2}{|c|}{$\begin{array}{c}\text { MP/ } \\
\text { CARCTERÍSTICA }\end{array}$} & $\mathbf{I}$ & II & III & IVa & IVb & $\mathbf{V}$ \\
\hline \multirow{2}{*}{ ÁREA } & Hectares & 157158,932 & 90839,455 & 118171,601 & 78377,324 & 36958,399 & 266440,438 \\
\hline & $\%$ & 22 & 12 & 16 & 10,5 & 4 & 35,5 \\
\hline PEDOLOGIA & Classes & $\begin{array}{c}58,3 \% \\
\text { Cambissolos } \\
13,6 \% \\
\text { Neossolos }\end{array}$ & $\begin{array}{c}96,5 \% \\
\text { Latossolos }\end{array}$ & $\begin{array}{c}84,6 \% \\
\text { Latossolos } \\
15,4 \% \text { Gleissolos }\end{array}$ & $\begin{array}{c}53,8 \% \\
\text { Latossolos } \\
45 \% \text { Argissolos }\end{array}$ & $\begin{array}{c}76,4 \% \\
\text { Latossolos } \\
23,6 \% \\
\text { Argissolos }\end{array}$ & $\begin{array}{c}92,3 \% \\
\text { Latossolos }\end{array}$ \\
\hline \multirow{3}{*}{ GEOLOGIA } & Litologia & $\begin{array}{c}51,1 \% \text { Areia } \\
\text { Fina a Grossa } \\
15,5 \% \text { Arenito } \\
\text { Eólico }\end{array}$ & $\begin{array}{l}\text { 50,1\% Arenitos } \\
\text { formados a } \\
\text { partir do } \\
\text { acúmulo de } \\
\text { sedimentos pela } \\
\text { ação do vento } \\
\text { (arenito eólico) } \\
\text { 32\% Basalto }\end{array}$ & $\begin{array}{c}82,8 \% \\
\text { Sedimento } \\
\text { Areno-Argiloso }\end{array}$ & $\begin{array}{l}78,1 \% \text { Arenito, } \\
\text { Conglomerado } \\
21,4 \% \text { Basalto }\end{array}$ & $\begin{array}{c}57,8 \% \\
\text { Sedimento } \\
\text { Areno-Argiloso } \\
34,2 \% \text { Basalto }\end{array}$ & $\begin{array}{l}\text { 64\% Arenito, } \\
\text { Conglomerado } \\
35 \% \text { Basalto }\end{array}$ \\
\hline & Grupo & $\begin{array}{l}\text { Cobertura } \\
\text { Quaternária }\end{array}$ & Grupo Paraná & $\begin{array}{l}\text { Cobertura } \\
\text { Terciária }\end{array}$ & $\begin{array}{l}\text { Grupo Bauru } \\
\text { Grupo Paraná }\end{array}$ & $\begin{array}{c}\text { Cobertura } \\
\text { Terciaria } \\
\text { Grupo Paraná }\end{array}$ & $\begin{array}{l}\text { Grupo Bauru } \\
\text { Grupo Paraná }\end{array}$ \\
\hline & Formação & $\begin{array}{c}\text { Cobertura } \\
\text { Arenosa } \\
\text { Indiferenciada }\end{array}$ & $\begin{array}{c}\text { Formação } \\
\text { Botucatu } \\
\text { Formação Serra } \\
\text { Geral }\end{array}$ & $\begin{array}{c}\text { Formação } \\
\text { Cachoeirinha }\end{array}$ & $\begin{array}{l}\text { Formação } \\
\text { Adamantina } \\
\text { Formação o } \\
\text { Serra Geral }\end{array}$ & $\begin{array}{c}\text { Formação } \\
\text { Cachoeirinha } \\
\text { Formação Serra } \\
\text { Geral }\end{array}$ & $\begin{array}{c}\text { Formação } \\
\text { Adamantina } \\
\text { Formação Serra } \\
\text { Geral }\end{array}$ \\
\hline \multirow{3}{*}{ RELEVO } & Geomorfologia & $\begin{array}{l}75,7 \% \text { Sup. } \\
\text { Reg. Apl com } \\
\text { dissecação fraca }\end{array}$ & $\begin{array}{l}\text { 68\% Sup. Reg. } \\
\text { Apl com } \\
\text { dissecação } \\
\text { média }\end{array}$ & $\begin{array}{l}\text { 70\% Sup. Reg. } \\
\text { Apl com } \\
\text { dissecação fraca }\end{array}$ & $\begin{array}{l}\text { 98,7\% Sup. Reg. } \\
\text { Apl com } \\
\text { dissecação } \\
\text { média }\end{array}$ & $\begin{array}{l}\text { 93\% Sup. Reg. } \\
\text { Apl com } \\
\text { dissecação } \\
\text { média }\end{array}$ & $\begin{array}{l}82,1 \% \text { Sup. Reg. } \\
\text { Apl com } \\
\text { dissecação } \\
\text { média }\end{array}$ \\
\hline & Hipsometria & $74 \% 1000$ & $54 \% 800$ & $51 \% 1000$ & $97 \% 800$ & $57 \% 1000$ & $88 \% 800$ \\
\hline & $\begin{array}{c}\text { Declividade } \\
\text { Abaixo de } 10 \%\end{array}$ & $86 \%$ & $70 \%$ & $80 \%$ & $83 \%$ & $80 \%$ & $84 \%$ \\
\hline \multicolumn{2}{|c|}{$\begin{array}{c}\text { USO } \\
\text { PREDOMINANTE }\end{array}$} & $\begin{array}{l}\text { Lavoura } \\
\text { temporária }\end{array}$ & $\begin{array}{c}\text { Agricultura e } \\
\text { pecuária restrita }\end{array}$ & $\begin{array}{l}\text { Lavoura } \\
\text { temporária }\end{array}$ & $\begin{array}{c}\text { Agriculturae } \\
\text { pecuária restrita }\end{array}$ & $\begin{array}{l}\text { Lavoura } \\
\text { temporária }\end{array}$ & $\begin{array}{c}\text { Pecuária } \\
\text { Vegetação nativa }\end{array}$ \\
\hline \multicolumn{2}{|c|}{$\begin{array}{c}\text { SUSCETIBILIDADE À EROSÃO } \\
\text { LINEAR }^{\alpha}\end{array}$} & $\begin{array}{l}\text { Topo: IV } \\
\text { Vertentes: I }\end{array}$ & III & $\begin{array}{c}\text { Topo: III } \\
\text { Cursos d'água: } \mathrm{V}\end{array}$ & $\begin{array}{l}\text { Terço Médio: II } \\
\text { Áreas planas:III }\end{array}$ & $\begin{array}{c}\text { Topo: III } \\
\text { Terço Médio: II }\end{array}$ & III \\
\hline \multicolumn{2}{|c|}{$\begin{array}{c}\text { CAPACIDADE DE USO } \\
\text { (a partir da Suscetibilidade à erosão } \\
\text { Linear) }\end{array}$} & $\begin{array}{l}\text { Topo:Classe III } \\
\text { Vertentes: } \\
\text { Classes VII e } \\
\text { VIII }\end{array}$ & Classe IV & $\begin{array}{l}\text { Topo:Classe II } \\
\text { Cursos d'água: } \\
\text { Classe VIII }\end{array}$ & Classe VI & Classe IV & Classe II \\
\hline \multicolumn{2}{|c|}{$\begin{array}{l}\text { CONFLITO NO USO ATUAL DO } \\
\text { SOLO }\end{array}$} & MÉDIO & BAIXO & BAIXO & MÉDIO & BAIXO & BAIXO \\
\hline
\end{tabular}




\section{CONCLUSÃO}

A metodologia e escala adotadas possibilitaram a distinção de cinco MP com características físico-ambientais homogêneas no interior de cada um deles. É importante ressaltar que a escala utilizada no presente traballho $(1: 250.000)$ é apropriada à análise regional feita por MP e não para análise em nível de detalhe.

Tendo como referência as características fisiográficas predominantes em cada um dos compartimentos definidos, foi possível analisar a suscetibilidade à erosão linear, a capacidade de uso das terras e os conflitos no uso atual do solo no município de Jataí. Os dados resultantes servem de subsídio para o planejamento do uso do solo do município.
A análise indica que não há áreas nas quais os conflitos do uso atual do solo sejam altos, o que sugere que o município encontra-se em relativo equilíbrio entre o suporte ecológico (no que diz respeito principalmente à susceptibilidade à erosão linear) e a exploração socioeconômica.

Entretanto, faz-se necessário fiscalização e controle das mudanças nos usos para que não ocorram problemas futuros relacionados à erosão linear, por exemplo, e em particular à compactação dos solos de textura média a argilosa. É importante o planejamento do uso do solo e atenção especial em relação aos condicionantes ambientais existentes na região.

\section{Notas}

${ }^{1}$ Legenda (Tabela 9):

$\alpha$ - Classes de Suscetibilidade: I Extremamente suscetível; II - Muito suscetível; III - Moderadamente suscetível; IV - Suscetível; v - Não suscetível.

$\beta$ - Classes de Capacidade da Terra de Jataí: Classe II - cultiváveis com problemas simples de erosão, podendo ser utilizadas com qualquer tipo de cultura, porém exigindo práticas simples de controle de erosão; Classe III -cultiváveis apenas ocasionalmente com problemas de erosão e conservação;
Classe IV - cultiváveis apenas ocasionalmente, onde os terrenos apresentam problemas complexos de conservação; indicados para pastagens e culturas perenes; Classe VI - Problemas de conservação, parcialmente favoráveis à ocupação por pastagens, sendo mais apropriados para reflorestamento; Classe VII - Problemas complexos de conservação, indicados para preservação ou reflorestamento; Classe VIII - áreas de proteção ambiental, onde os terrenos apresentam problemas complexos de conservação.

\section{Referências Bibliográficas}

ANTUNES, E. C. 2006. Recuperação de áreas degradadas por meio de recomposição vegetal em solos arenosos no sudoeste goiano. Tese de Doutorado - Programa de Pós-graduação em Ciências Ambientais, Universidade Federal de Goiás, Goiânia.

CARMO, R.L. do; GUIMARÃES, E. \& AZEVEDO, A.M.M. de. 2002. Agroindústria, População e Ambiente no Sudoeste de Goiás. XIII Encontro da Associação Brasileira de Estudos Populacionais. Ouro Preto (MG).
CASTRO, S.S. \& SALOMÃO, F.X.T. 2000. Compartimentação Morfopedológica: considerações metodológicas. GEOUSP № 7, p.2935, São Paulo.

EITEN, G. 1993. Vegetação do Cerrado. In: Pinto, N. Cerrado. (ed.), $2^{a}$ edição, Edunb / SEMATEC, Brasília.

EMBRAPA. Centro Nacional de Pesquisas de Solos. 1997. Manual de métodos de análise do solo. 2.ed. rev. Atual. Rio de Janeiro, 212p. 
GALINKIN, M. (ed.). 2003. GeoGoiás 2002. Goiânia: Agência Ambiental de Goiás; Fundação CEBRAC; PNUMA; SEMARH.

IBGE. Instituto Brasileiro de Geografia e Estatística. 2006. Censo Agropecuário. Site visitado em 05 de fevereiro de 2008. Disponível em http://www.ibge.gov.br/cidadesat/default.php

INPE. Instituto Nacional de Pesquisas Espaciais. Catálogo de Imagens CBERS. Site visitado em 22 de janeiro de 2008. Disponível em http:// www.cbers. inpe. $\mathrm{br} / \mathrm{?hl}=\mathrm{pt}$

KAGEYAMA, A. (Coord.). 1990. O novo padrão agrícola brasileiro: do complexo rural aos complexos agroindustriais. In: WALTER, Belik et al. 1990. Agricultura e Políticas Públicas. Brasília: Série IPEA, n. ${ }^{\circ}$ 127. p. 113-222.

LEPSCH, I (Org). 1991. Manual para o Levantamento do Meio Físico de Classificação das Terras no Sistema de Capacidade de Uso. Campinas: Soc. Bras.de Ciência do Solo.

LEPSCH, I. 2002. Formação e conservação dos solos. São Paulo: Oficina de Textos.

MIZIARA, F. 2006. Expansão de Fronteiras e Ocupação do Espaço no Cerrado: o Caso de Goiás. In: GUIMARÃES, L.D.; SILVA, M.A.D. da \& ANACLETO, T.C. (org.). Natureza Viva: Cerrado. Ed. da UCG.

NASA. National Aeronautics and Space Administration. 2007. Shuttle Radar Topography Mission - SRTM. Site visitado em 20 de outubro de 2007 Disponível em http:// www2.jpl.nasa.gov/srtm/costaric.htm

PNUD. Programa das Nações Unidas para o Desenvolvimento. 2003. Atlas do Desenvolvimento Humano no Brasil. Site visitado em 02 de fevereiro de 2008. Disponível em http://www.pnud.org.br/atlas/
RADAMBRASIL. Ministério das Minas e Energia. Secretaria Geral. Geologia, geomorfologia, pedologia, vegetação e uso potencial da terra. Levantamento de Recursos Naturais, Rio de Janeiro. 1982.

RESENDE, M., N., C., RESENDE, S. B. \& CORRÊA, G. D. 2002. Pedologia: Base para distinção de Ambientes. Viçosa: NEPUT.

RIBEIRO, J. C.; SALOMÃO, F. X. T. 2003. Abordagem Morfopedológica Aplicada ao Diagnóstico e Prevenção de Processos Erosivos na Bacia Hidrográfica do Alto Rio da Casca, MT. São Paulo, UNESP, Geociências, v. 22, n. 1, p. 83-95.

RIZZINI, C. T. 1979. Tratado de Fitogeografia do Brasil. Ed. da Universidade de São Paulo, HUCITEC. São Paulo, 1976.

RODRIGUES, E.; RODRIGUES, S.; PASQUALETTO, A. 2003. O desmatamento legal em Goiás para atividades de agricultura e pecuária de 2000 a 2002. Disponível em http://www.ucg.br/nupenge/ pdf/0001.pdf.

SALOMÃO, F. X. T. 1999. Controle e prevenção dos processos erosivos. In: GUERRA, T.A.J.; SILVA, A.S. \& BOTELHO, R.G. (Organizadores). Erosão e Conservação dos solos: conceitos, temas e aplicações. Rio de Janeiro: Bertrand Brasil, p. 229-265.

SEAGRO. Secretaria de Agricultura do Estado de Goiás. Site visitado em 20 de janeiro de 2008. http://www.agronegocio.goias.gov.br/ docs/portal/estrutura.pdf

SIEG. Sistema Estadual de Estatística e de Informações Geográficas de Goiás SECRETARIA DE PLANEJAMENTO E DESENVOLVIMENTO DE GOIÁS. Site visitado em 29 de janeiro de 2008. Disponível em http:// www.sieg.go.gov.br/ 
SILVA, R. A. 2006. Arenização/Desertificação no Setor Sul da Alta Bacia do Rio Araguaia (GO/ $M T)$ : distribuição e fatores condicionantes de formação dos areais. Dissertação de mestrado.
Programa de Pesquisa e Pós-graduação em Geografia, Instituto de Estudos SócioAmbientais, Universidade Federal de Goiás.

Trabalho enviado em novembro de 2008 Trabalho aceito em agosto de 2009 
